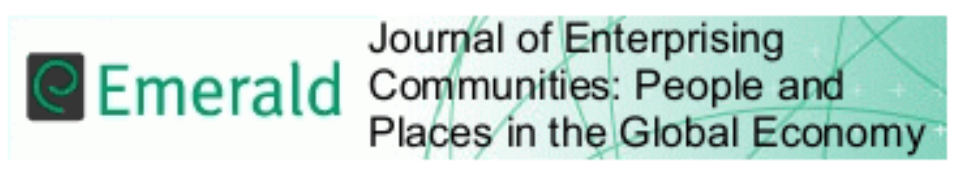

\title{
Digital Transformation in West Africa: A two country, two- sector analysis
}

\begin{tabular}{|r|l|}
\hline Journal: & $\begin{array}{l}\text { Journal of Enterprising Communities: People and Places in the Global } \\
\text { Economy }\end{array}$ \\
\hline Manuscript ID & JEC-06-2020-0114 \\
\hline Manuscript Type: & Academic Papers \\
\hline Keywords: & $\begin{array}{l}\text { Agricultural Technology, Digital Transformation, Media Technology, } \\
\text { Ghana, Nigeria, West Africa }\end{array}$ \\
\hline
\end{tabular}

\section{SCHOLARONE ${ }^{m}$ Manuscripts}




\title{
Digital Transformation in West Africa: A two country, two-sector analysis
}

\author{
Abstract \\ Purpose - This study explores opportunities and challenges of accelerating digital \\ entrepreneurship development in key economic growth sectors in West Africa.
}

Design/ Approach/Methodology - The study uses case illustrations from the media and agriculture sectors to highlight some of the opportunities and challenges that have shaped current business practices in this digital space in West Africa.

Findings - Technological infrastructure featured as one of the main challenges for fostering success in the media-tech cases and perhaps linked to the low internet penetration rates. Likewise, infrastructure proved to be a challenge in the agri-tech sector cases.

Originality/ value - This study highlights the importance of partnerships within the entrepreneurship ecosystems as a critical condition for ensuring positive benefits for all stakeholders within the entrepreneurial ecosystem taken from the lens of West Africa.

Keywords: Agricultural Technology, Digital Transformation, Entrepreneurial Ecosystems, Media Technology, West Africa, Ghana, Nigeria

\section{Introduction}

The continent of Africa is characterised by a plethora of complex events such as military conflicts, political uncertainty, and unemployment with associated food shortages, societal inequality as a result of gender imbalance, poor quality education and digital illiteracy, - all present the reality for the most of countries in the Sub-Saharan Africa (SSA). However, we are witnessing new business models and approaches created and implemented to overcome such events and trigger unique opportunities for the regional development. As Madichie (2016) noted, these innovative solutions are largely fragmented. Joseph, Erasmus \& Marnewick (2014) also previously argued that many innovative entrepreneurial ventures fail due to inability to execute projects and the lack of very critical for the entrepreneurial success soft skills.

Digitalisation through both the adoption and use of digital technologies present transformative prospects for the cultivation of the entrepreneurial ecosystem (Asongu \& Nwachukwu 2018). Digital technologies enable flow, openness and accessibility of information and communication that indeed breakdown barriers to education, shaping independent thinking and fostering self-employment practices. It is also paramount to highlight that digital technologies are means to express "aspirations and senses of being in the world" (Pijnaker \& Spronk 2017). In other words, adoption and use of digital technologies in the SSA, on one hand, enables social and economic change due to ability to capture cultural 
traditions and legacy as well as all contextual intricacies of the region. On the other hand, it enables connectivity with much more developed practices and experiences elsewhere.

Dana et al. (2018) pointed out that despite predictability and theoretical assumptions of the impact digital technologies on entrepreneurship, research on digital entrepreneurship in SSA remains either scarce or exudes limited understanding of the potential contribution of digital entrepreneurship on economic growth and societal benefit. Consequently, this study explores what opportunities and challenges of accelerating entrepreneurship in SSA as mediated by digitalisation. It does this by drawing upon insights from two key, but oft neglected sectors (i.e. media and agriculture) on the continent and with a focus on two West African economies - Ghana and Nigeria.

\section{African entrepreneurship: Theoretical background}

Entrepreneurship is a social technology for creating business opportunities (Welter et al. 2017). In addition to the common perspective on defining entrepreneurship, various studies (i.e. Tvedten et al. 2014; Ratten \& Jones 2018) argue that entrepreneurship is a solution to the economic and social problems in parts of Africa. It is due to independence and control perceived to be an ultimate outcome of any entrepreneurial activity. This enables the improvement of the quality of life, as well as develops communities that are inspired to achieve industrial growth. It is, therefore, not surprising to see that Africans have "the highest entrepreneurial intent globally" (Reid et al. 2015, p. 264).

However, such entrepreneurial intent is not converted in to a number of successful business ventures because of the geopolitical nuances, discussed in the introductory section, but also mistaken beliefs of the entrepreneurship being a 'way of making it' in the society that lacks educational and employability prospects (Ferreira et al. 2017).

Moreover, abundance of institutionalised, state-owned, and controlled enterprises in SSA creates barriers in terms of availability of financial investments and lack of selfconfidence in creating new start-ups and small business activities (Edoho 2016; Ratten \& Jones 2018; Madichie, Nkamnebe \& Ekanem, 2020). It is, therefore, clear that an institutionalised support via investments, education provisions and structural support for the entrepreneurship are inevitable criteria for increasing entrepreneurial activities in SSA.

In understanding what makes entrepreneurial ventures successful in SSA, it is important to first explore the cultural and historical nuances that set aside this region of the world (Tvedten et al. 2014). Despite the popularity of SSA entrepreneurship in the media, there is still a lack of understanding in the academic literature about how it is different 
compared to other geographical locations (see Table 1). An individual country and sectorial insights within the region are necessary to expand our knowledge on the region.

\section{Take in Table 1.}

Lately, few studies explored impact of various socio-political and institutional aspects on entrepreneurial activities in SSA. One of these is study by Hain \& Jurowetzki (2018) emphasised the importance of foreign direct investments into the entrepreneurship ecosystems of SSA. In particular, such investments are found to increase longevity of the start-ups and contribute to resources and capabilities enhancement in the entrepreneurial businesses that provide technical innovations of global significance. Such innovations are developed at the intersection of global and local knowledge (Madichie et al. 2019).

Boojihawon \& Ngoasong (2018) not long ago focused on the entrepreneurial digital competencies and its effect on success of digital entrepreneurial ventures, taking into account limited resources of an African country, Cameroon. It was highlighted that the information and communication technology infrastructure, transport and local distribution infrastructure and training opportunities to develop the entrepreneurial digital competencies are key to fostering digital enterprises' development and growth. Shemi \& Procter (2018) followed up on this and focused on social commerce adoption in the context of small and medium sized enterprises (SMEs) using a contextualism theory. It was clear that in the SSA context, social media networks such as Facebook are increasingly used to enable transactional or trade exchanges with no barriers for entry but enthusiasm to carry on entrepreneurial practices in less resource intensive technological context.

In addition to focus on digitalisation, several recent studies (i.e. Ukanwa et al. 2018; Gudeta \& Van Engen 2018; Nziku \& Struthers 2018, Taura et al., 2019) looked into women entrepreneurship in particular. Ukanwa et al. (2018) highlights that females in rural areas are particularly vulnerable and disadvantaged group; hence, entrepreneurship has potential to change such dynamics and empower this deprived social group. It was found that many women could combine household responsibilities can be combined with an opportunities to earn living wage.

However, microfinance options and process of obtaining are not tailored to limit barriers for women in rural areas. There are also social and cultural aspects that prevent women in Africa to take on risk and start a business venture (Nziku \& Struthers 2018; Madichie, Nkamnebe \& Ekanem, 2020). Many women rely on views and opinions of their 
immediate social circles when many are discouraged to commit to self-employment as it presents more risks and uncertainty rather than employment with a larger organisation.

Finally, other cultural context such as Ethiopia limit opportunities for women to maintain work-life balance, hence discourage women to start own businesses and even 'be brave' to undertake any employability (Gudeta \& Van Engen 2018). It is evident that many of barriers now longer seen to be true for western economies remain reality for the SSA region and at the same it is also clear that cultural differences present unique opportunities for the entrepreneurial miracles in the region, learning from which can benefit the rest of the world.

\section{Entrepreneurial Ecosystems}

The entrepreneurial ecosystem approach have recently emerged as a benchmark for implementing policies leading to a healthy and thriving critical mass of digital enterprises. Entrepreneurship ecosystem scholars have argued that, an entrepreneurial setting rich in thriving ecosystem leads to more productive entrepreneurial output (Stam, 2013; Mason \& Brown, 2014; Mack \& Mayer, 2016; Alvedalen \& Boschma, 2017). A healthy ecosystem is pivotal to thriving entrepreneurship and economic development (Sheriff \& Muffatto 2015). Entrepreneurship ecosystem has been heralded as one of the few entrepreneurship approaches to recognise both the central role of 'entrepreneurial actor' and the 'strategic context' of the productive enterprise system (Stam, 2013). This enables the approach to integrate both evolutionary and strategic approaches making it an ideal candidate for application to quintessentially African settings (Sheriff \& Muffatto 2015).

Sceptics, however, argues that entrepreneurship ecosystem approach has shortcomings since it is concerned with a complex system of interdependent parts considered as dichotomous binary relationship of 'either/or' logic instead of 'both/and' (Clarke et al. 2014). Having said that, scholars argue that it has more benefits than shortcomings since, in a typical African context its potential to capture the specificity and idiosyncrasy of local systems is well pronounced (Sheriff \& Muffatto 2015). When applied in digital settings, it has the power to generate insights about knowledge exchange flows (energy), and venture capital (nutrient) necessary for an enduring and dynamic digital system of enterprise.

Unfortunately, despite the potential to generate insights, African research rarely evaluates the challenges and prospects of entrepreneurial ecosystems especially in digital environments of emerging less developed countries (Kantis \& Federico, 2012; Taura et al., 2019). Notable exceptions include Sheriff \& Muffatto (2015) who conducted a cross- 


\section{Design/ Approach/ Methodology}

For the purpose of this study, the multiple case approach was adopted. Multiple cases (Rowley 2002) from different sectors affected by the digitalisation in SSA, media (hereafter media-tech) and agriculture (hereafter agri-tech), present the sample. Multiple cases with combination of empirical interviews and retrospective analysis of secondary interviews are widely used in the research concerning entrepreneurship (Chandler and Lyon 2001). Table 2 presents full details on the sample.

\section{Take in Table 2.}

Most respondents were in 'media-tech' and linked to Nigeria while three of the five respondents in 'agritech' were Ghana-based ventures. Multiple data collection approaches were used to profile the cases, including primary and secondary interviews with business owners and employees. Both thematic analysis (Braun and Clarke 2006) and content analysis (Elo \& Kyngäs 2008) were drawn upon in interview data analysis with the aim to highlight the challenges and opportunities of accelerating entrepreneurship in SSA as a result of digitalisation. 


\section{Discussion of Findings}

The study finds, and presents the range of challenges and opportunities of accelerating entrepreneurship as a result of digitalisation, identified across media- and agri-tech sectors. These themes are analysed starting with the challenges and then moving on to the opportunities.

\subsection{Challenges}

\section{Media-tech}

Technological infrastructure featured as one of the main challenges for fostering success amongst studies companies. It is was not surprising to see this aspect highlighted as Nigeria and the whole SSA region lag behind on technological advancements and quite low Internet penetration rates. Moreover, quality of mobile network connectivity is diverse throughout Nigeria leaving many rural areas being inaccessible and reliant of fixed network connectivity. This was also highlighted by Bolat (2019) in her review of challenges faced by media SMEs in Nigeria. As confirmed by Madichie et al. (2019), within Nollywood cases it was also clear that production, distribution and marketing of content are seen as challenging due to "disorganised" approaches associated with commercialisation of film and media products. This is where corruption and self-interests of individual industry players overtake the benefits and progress of the entire ecosystem.

Being a historical characteristic of the most Nigerian business environments (Cage 2015), corruption remains one of the main challenges to accelerating growth of modern Nigerian tech-businesses. This is closely linked to sources of funding available to businesses willing to digitalise and benefit from new opportunities presented to tech-infused media businesses. Although number of funding opportunities is much more diverse today than a decade ago, limited amount of funding available and heavy reliance of foreign sources of funding restricts Nigerian media-tech businesses to expand and grow their operations and profitability (Bolat 2019; Madichie et al. 2019; Madichie, Nkamnebe \& Ekanem, 2020). Indeed, this creates tensions within the industry and fosters corruption. For instance, in the case of Nollywood, it is clear that marketing is not seen as specific area of attention and hence monetary investment. This in turn prevents films to be distributed and hence monetised. 


\subsection{Opportunities}

Having highlighted the challenges, we now turn to the opportunities in these sectors.

\section{Media-tech}

The mindset of the first reported firm, 'Mobil first,' was largely highlighted by the advertising businesses as presenting particular opportunities for the Sub-Saharan region due to limitations of overall technological infrastructure. It is clear that in terms of overcoming distribution and marketing issues associated with commercialisation of content, marketing platforms are seen as main channel to push the media products and services. As Bolat (2019) suggests such focus could help to streamline the production and distribution and enable much more focused approach to who are critical actors within the commercialisation ecosystem.

Indigenous practices of using and deploying technology are clearly in place amongst all of the cases we studied. This is as a result of cultural nuances but also unique talent available in the SSA region. Culture is largely important to inspiration and purpose of mediatech cases. Embracing social causes, producing stories that discuss differences of SSA is what presents great competitive advantage for media-tech businesses in Nigeria (Cage 2015; Bolat 2019; Madichie et al. 2019). This combined with the latest globally accepted media production skills and approaches (coming from graduates who obtain foreign qualifications), 
but with portrayal of unique stories definitely was highlighted as a differentiation point that is of interest not only to the SSA market but media audiences worldwide.

The expansion and use of networks, were seen to be valuable to all of the cases analysed in this study. This is not surprising because SSA culture is known for its partnership culture. However, as previously discussed, this is in neighbourhood with self-interests and corruption behaviour. Hence, such tensions should be resolved first. Indeed, the list of challenges and opportunities identified from the investigated cases within the media-tech sector in particular, demonstrate that although skills, partnerships and networks could advance further all current efforts in the industry via available talent, established partnerships, key element of preventing such advancements to take place - technological infrastructure - is yet to be established in Nigeria. Furthermore, some of historical and cultural nuances accompanied by corruption use limits of the infrastructure to own benefits, hence, slowing any positive progress for business beneficiaries. Change in mindsets is what should happen first, in order for the ecosystem to develop and see legitimacy as vitamin for successful grow of media-tech businesses in SSA (Taura et al. 2019).

\section{Agri-tech}

There are indications that innovation in agricultural activities requiring the deployment of digital tech, play a significant role in fighting poverty, lowering per unit costs of production (Kassie et al. 2011), as well as in boosting rural incomes and reducing hunger (Maertens \& Barrett 2013; Acheampong \& Hinson 2018, Acheampong 2019). However, many farmers continue to face economic pressures - both micro and macro - with negative impact on farm productivity (Boere \& van Kooten 2015). This is especially visible in the ever-increasing divide between urban and rural localities. This implies that agriculture needs to increase innovation and technology adoption in rural remote areas. As with the media-tech, 'mobil first' mindset was emphasised by the agri-tech cases. It was clear that all of the opportunities identified in the deploying tech to assist famers come from the needs to access and transmit data, communicate, complete transactions in the remote, time and location-sensitive context.

Digital transformation was clear opportunity highlighted by the studies agri-tech businesses. However, it was evident from all the cases that digital transformation needs to happen within a wider agri-tech ecosystem that includes conventional agribusinesses, i.e. farms, but also tech solution providers, players controlling technological infrastructure, governmental and non-governmental organisations. It was apparent that partnership mentality is needed to establish the ecosystem and digital transformation come to fruition. For instance, 


\section{Conclusions and Implications}

Two sectors were examined in this study and they both highlight similarities in regard to the challenges and opportunities faced by the entrepreneurial firms in the digital space in SSA. It is clear that developments in infrastructure is the main issue to be resolved before any deployment of digital tech to become mainstream and benefit businesses. Moreover, entrepreneurship ecosystems are critical to stimulating entrepreneurial intent to deploy technology, acquire skills and engage with opportunities offered by digital tech (Sheriff \& Muffatto 2015). The African Development Bank Group (2019) did point out that productivity can only "be achieved if constraints to doing business such as poor governance, low institutional quality, and inadequate infrastructure" will no longer limit "firm survival and dynamism". Our findings confirm this claim.

It was not too long ago that McKinsey (2019) reported that in Africa "for someone to find a consumer, you need to have a local partner who knows where the consumer is, based on very subjective information". This study has also highlighted the importance of partnerships within the entrepreneurship ecosystems and critical condition for the positive benefits for all stakeholders within the ecosystem. In today's competitive business environment, it is clear that both the media and agricultural technology (agri-tech) sectors see benefits in deploying digital tech. Hence, both sectors play significant role in economic developments of SSA. It is clear that digital tech provide media-tech and agri-tech businesses with opportunity to take into account the regional nuances of societal, institutional and geographical nature. 


\section{References}

Acheampong, G., \& Hinson, R. E. (2018). Benefitting from Alter Resources: Network Diffusion and SME Survival. Journal of Small Business \& Entrepreneurship, 30(1), $1-18$.

Acheampong, G. (2019). The Nature of Corporate Digital Agricultural Entrepreneurship in Ghana. In Taura, N. D., Bolat, E. \& Madichie, N. (Eds.) Digital Entrepreneurship in Sub-Saharan Africa Challenges, Opportunities and Prospects. Palgrave Macmillan. doi: 10.1007/978-3-030-04924-9

African Development Bank Group (2019). African Economic Outlook 2019. Available at: https://www.afdb.org/en/knowledge/publications/african-economic-outlook/

Alvedalen, J., \& Boschma, R. (2017). A critical review of entrepreneurial ecosystems research: Towards a future research agenda. European Planning Studies, 25(6), 887903.

Asongu, S. A., \& Nwachukwu, J. C. (2018). Openness, ICT and entrepreneurship in subSaharan Africa. Information Technology \& People, 31(1), 278-303.

Boere, E., \& van Kooten, G. C. (2015). Reforming the Common Agricultural Policy: Decoupling Agricultural Payments from Production and Promoting the Environment. Working Paper No. 2015-01. REPA Research Group, Department of Economics University of Victoria, Wellington.

Bolat, E. (2019). The African New Media Digital Revolution: Some Selected Cases from Nigeria. In Taura, N. D., Bolat, E. \& Madichie, N. (2019) (Eds.) Digital Entrepreneurship in Sub-Saharan Africa Challenges, Opportunities and Prospects. Palgrave Macmillan. Doi: 10.1007/978-3-030-04924-9

Boojihawon, D. K., \& Ngoasong, Z. M. (2018). Emerging digital business models in developing economies: The case of Cameroon. Strategic Change, 27(2), 129-137.

Braun, V. and Clarke, V., 2006. Using thematic analysis in psychology. Qualitative Research in Psychology, 3(2), pp.77-101.

Cage, J. (2015). The Economics of the African Media. In C. Monga \& J. Y. Lin (Eds.), The Oxford Handbook of Africa and Economics: Volume 2: Policies and Practices (pp. 605-625). Oxford: Oxford University Press.

Chandler, G.N. and Lyon, D.W., 2001. Issues of research design and construct measurement in entrepreneurship research: The past decade. Entrepreneurship Theory and Practice, 25(4), pp.101-113. 
Clarke, J., Holt, R., and Brundel, R. (2014). Re-imagining the growth process: (co)-evolving metaphorical representations of entrepreneurial growth. Entrepreneurship \& Regional Development, 26 (3-4), 234-256

Dana, L. P., Ratten, V., \& Honyenuga, B. Q. (Eds.). (2018). African Entrepreneurship: Challenges and Opportunities for Doing Business. Springer.

Edoho, F. M. (2016). Entrepreneurship paradigm in the new millennium: A critique of public policy on entrepreneurship. Journal of Entrepreneurship in Emerging Economies, 8(2), 279-294.

Elo, S., \& Kyngäs, H. (2008). The qualitative content analysis process. Journal of advanced nursing, 62(1), 107-115.

Ferreira, J. J., Fernandes, C. I., \& Ratten, V. (2017). Entrepreneurship, innovation and competitiveness: what is the connection? International Journal of Business and Globalisation, 18(1), 73-95.

Gudeta, K. H., \& van Engen, M. L. (2018). Work-life boundary management styles of women entrepreneurs in Ethiopia - "choice" or imposition? Journal of Small Business and Enterprise Development, 25(3), 368-386.

Hain, D. S., \& Jurowetzki, R. (2018). Local competence building and international venture capital in low-income countries: Exploring foreign high-tech investments in Kenya's Silicon Savanna. Journal of Small Business and Enterprise Development, 25(3), 447482.

Igwe, P. A., Madichie, N., \& Newbery, R. (2019). Determinants of livelihood choices and artisanal entrepreneurship in Nigeria. International Journal of Entrepreneurial Behaviour and Research, 25(4), 674-697.

Joseph, N., Erasmus, W., \& Marnewick, C. (2014). The Idle State of Information and Communication Technology Project Management. Journal of African Business, 15(3), 184-196.

Kantis, H.D. \& Federico, J.S. (2012), Entrepreneurial Ecosystems in Latin America: the role of policies Entrepreneurial Development Programme (PRODEM)", - Institute of Industry, Universidad Nacional de General Sarmiento, Los Polvorines, Buenos Aries.

Kassie, M., Shiferaw, B., \& Muricho, G. (2011). Agricultural Technology, Crop Income, and Poverty Alleviation in Uganda. World Development, 39(10), 1784-1795.

Klerkx, L., Aarts, N., \& Leeuwis, C. (2010). Adaptive Management in Agricultural Innovation Systems: The Interactions between Innovation Networks and Their Environment. Agricultural Systems, 103(6), 390-400. 
Mack, E., \& Mayer, H. (2016). The evolutionary dynamics of entrepreneurial ecosystems. Urban Studies, 53(10), 2118-2133.

Madichie, N. (2016) Editorial - Introduction to the Issue. African Journal of Business and Economic Research, 11(2/3), 5-8.

Madichie, N., Nkamnebe, AD \& Ekanem, IU (2020) Marketing in the Informal Economy: An Entrepreneurial Perspective and Research Agenda. In: Nwankwo, S., \& Gbadamosi, A. (Eds.) Entrepreneurship Marketing: Principles and Practice of SME Marketing, 2nd Edition. London: Routledge. (Chapter 26).

Madichie, N., Ajakaiye, B. O. \& Ratten, V. (2019). The Impact of New Media (Digital) and Globalisation on Nollywood. In Taura, N. D., Bolat, E. \& Madichie, N. O. (Eds.) Digital Entrepreneurship in Sub-Saharan Africa Challenges, Opportunities and Prospects. Palgrave Macmillan. doi: 10.1007/978-3-030-04924-9

Maertens, A., \& Barrett, C. B. (2013). Measuring Social Networks' Effects on Agricultural Technology Adoption. American Journal of Agricultural Economics, 95(2), 353-359.

Maroufkhani, P., Wagner, R., \& Wan Ismail, W. (2018) Entrepreneurial ecosystems: a systematic review, Journal of Enterprising Communities: People and Places in the Global Economy, 12(4), 545- 564, https://doi.org/10.1108/JEC-03-2017-0025

Mason, C., \& Brown, R. (2014). Entrepreneurial ecosystems and growth oriented entrepreneurship. Final Report to OECD, Paris, 30(1), 77-102.

McKinsey (2019). How e-commerce supports African business growth. January. Available at: https://www.mckinsey.com/featured-insights/middle-east-and-africa/howecommerce-supports-african-business-growth

Nziku, D. M., \& Struthers, J. J. (2018). Female entrepreneurship in Africa: Strength of weak ties in mitigating principal-agent problems. Journal of Small Business and Enterprise Development, 25(3), 349-367.

Ratten V., \& Jones P. (2018) Bringing Africa into Entrepreneurship Research. In: Dana LP., Ratten V., Honyenuga B. (Eds.) African Entrepreneurship. Palgrave Studies of Entrepreneurship in Africa. Palgrave Macmillan, Cham.

Reid, M., Roumpi, D., \& O’Leary-Kelly, A. M. (2015). Spirited women: The role of spirituality in the lives of female entrepreneurs in Ghana. African Journal of Management, 1(3), 264-283.

Rowley, J. (2002). Using case studies in research. Management research news, 25(1), 16-27. 
Rybaczewska, M. \& Sparks, L. (2019), Place marketing and place based loyalty schemes, Journal of Enterprising Communities: People and Places in the Global Economy, 14(1), 42-56. https://doi.org/10.1108/JEC-09-2019-0094

Shemi, A. P., \& Procter, C. (2018). E-commerce and entrepreneurship in SMEs: case of myBot. Journal of Small Business and Enterprise Development, 25(3), 501520, https://doi.org/10.1108/JSBED-03-2017-0088

Sheriff, M., \& Muffatto, M. (2015). The present state of entrepreneurship eco- systems in selected countries in Africa. African Journal of Economic and Management Studies, $6,17-54$.

Susan, F. \& Acs, Z. J. (2017). The digital entrepreneurial ecosystem, Small Business Economics 49(1), 55-73.

Stam, E. (2013). Knowledge and Entrepreneurial Employees: A Country Level Analysis. Small Business Economics, 41(4), 887-898

Taura, N. D., Bolat, E. \& Madichie, N. (2019). (Eds.) Digital Entrepreneurship in SubSaharan Africa Challenges, Opportunities and Prospects. Palgrave Macmillan. Doi: 10.1007/978-3-030-04924-9

Taura, N. D., Ede, O. C. \& Ogunniyi, O. (2019). Renegotiating Legitimacy in the Digital Age: Insights from Nigeria. In Taura, N. D., Bolat, E. \& Madichie, N. O.

(Eds.) Digital Entrepreneurship in Sub-Saharan Africa Challenges, Opportunities and Prospects. Palgrave Macmillan. Doi: 10.1007/978-3-030-04924-9

Tvedten, K., Wendelboe Hansen, M., \& Jeppesen, S. (2014). Understanding the rise of African business: In search of business perspectives on African enterprise development. African Journal of Economic and Management Studies, 5(3), 249-268.

Welter, F., Baker, T., Audretsch, D. B., \& Gartner, W. B. (2017). Everyday entrepreneurship: a call for entrepreneurship research to embrace entrepreneurial diversity. Entrepreneurship: Theory \& Practice, 41(3), 311-321.

Ukanwa, I., Xiong, L., \& Anderson, A. (2018). Experiencing microfinance: effects on poor women entrepreneurs' livelihood strategies. Journal of Small Business and Enterprise Development, 25(3), 428-446. 
Table 1. Sample studies

\begin{tabular}{|c|c|c|}
\hline Author/ Year & Title & Country \\
\hline Chege \& Wang (2020). & $\begin{array}{l}\text { The impact of technology transfer on agribusiness } \\
\text { performance in Kenya. }\end{array}$ & Kenya \\
\hline Acheampong (2019). & $\begin{array}{l}\text { The Nature of Corporate Digital Agricultural } \\
\text { Entrepreneurship in Ghana. }\end{array}$ & Ghana. \\
\hline $\begin{array}{l}\text { Igwe, P. A., Madichie, } \\
\text { N., \& Newbery, R. } \\
\text { (2019). }\end{array}$ & $\begin{array}{l}\text { Determinants of livelihood choices and artisanal } \\
\text { entrepreneurship in Nigeria }\end{array}$ & Nigeria \\
\hline $\begin{array}{l}\text { Boojihawon \& } \\
\text { Ngoasong (2018). }\end{array}$ & $\begin{array}{l}\text { Emerging digital business models in developing economies: } \\
\text { The case of Cameroon. }\end{array}$ & Cameroon \\
\hline $\begin{array}{l}\text { Azumah, Donkoh \& } \\
\text { Awuni (2018). }\end{array}$ & $\begin{array}{l}\text { The perceived effectiveness of agricultural technology transfer } \\
\text { methods: Evidence from rice farmers in Northern Ghana. }\end{array}$ & Ghana \\
\hline $\begin{array}{l}\text { Hain \& Jurowetzki } \\
\text { (2018). }\end{array}$ & $\begin{array}{l}\text { Local competence building and international venture capital in } \\
\text { low-income countries: Exploring foreign high-tech } \\
\text { investments in Kenya's Silicon Savanna. }\end{array}$ & Kenya \\
\hline $\begin{array}{l}\text { Eberhardt \& Vollrath } \\
\text { (2018). }\end{array}$ & $\begin{array}{l}\text { The effect of agricultural technology on the speed of } \\
\text { development. }\end{array}$ & South Korea \\
\hline $\begin{array}{l}\text { Feder \& Savastano } \\
(2017) \text {. }\end{array}$ & $\begin{array}{l}\text { Modern agricultural technology adoption in sub-Saharan } \\
\text { Africa: A four-country analysis. }\end{array}$ & $\begin{array}{l}\text { Ethiopia, Niger, } \\
\text { Nigeria, Tanzania }\end{array}$ \\
\hline $\begin{array}{l}\text { Pamuk, Bulte \& } \\
\text { Adekunle (2014). }\end{array}$ & $\begin{array}{l}\text { Do decentralized innovation systems promote agricultural } \\
\text { technology adoption? Experimental evidence from Africa. }\end{array}$ & Africa \\
\hline $\begin{array}{l}\text { Abebaw \& Haile } \\
\text { (2013). }\end{array}$ & $\begin{array}{l}\text { The impact of cooperatives on agricultural technology } \\
\text { adoption: Empirical evidence from Ethiopia. }\end{array}$ & Ethiopia \\
\hline $\begin{array}{l}\text { Muzari, Gatsi \& } \\
\text { Muvhunzi (2012). }\end{array}$ & $\begin{array}{l}\text { The impacts of technology adoption on smallholder } \\
\text { agricultural productivity in sub-Saharan Africa: A review. }\end{array}$ & Africa \\
\hline $\begin{array}{l}\text { Asfaw, Shiferaw, } \\
\text { Simtowe \& Haile } \\
(2011) \text {. }\end{array}$ & $\begin{array}{l}\text { Agricultural technology adoption, seed access constraints and } \\
\text { commercialization in Ethiopia. }\end{array}$ & Ethiopia \\
\hline $\begin{array}{l}\text { Kassie, Shiferaw \& } \\
\text { Muricho (2011) }\end{array}$ & $\begin{array}{l}\text { Agricultural technology, crop income, and poverty alleviation } \\
\text { in Uganda. }\end{array}$ & Uganda \\
\hline $\begin{array}{l}\text { Uaiene, Arndt \& } \\
\text { Masters (2009). }\end{array}$ & $\begin{array}{l}\text { Determinants of agricultural technology adoption in } \\
\text { Mozambique. }\end{array}$ & Mozambique \\
\hline $\begin{array}{l}\text { Minten \& Barrett } \\
\text { (2008). }\end{array}$ & $\begin{array}{l}\text { Agricultural technology, productivity, and poverty in } \\
\text { Madagascar. }\end{array}$ & Madagascar \\
\hline Alzouma (2005). & $\begin{array}{l}\text { Myths of digital technology in Africa: Leapfrogging } \\
\text { development? }\end{array}$ & Africa \\
\hline $\begin{array}{l}\text { De Janvry \& Sadoulet } \\
\text { (2002). }\end{array}$ & $\begin{array}{l}\text { World poverty and the role of agricultural technology: direct } \\
\text { and indirect effects. }\end{array}$ & $\begin{array}{l}\text { Africa, Asia, and } \\
\text { Latin America }\end{array}$ \\
\hline Doss (2001). & $\begin{array}{l}\text { Designing agricultural technology for African women } \\
\text { farmers: Lessons from } 25 \text { years of experience. }\end{array}$ & Africa \\
\hline Arndt \& Tarp (2000). & $\begin{array}{l}\text { Agricultural technology, risk, and gender: A CGE analysis of } \\
\text { Mozambique. }\end{array}$ & Mozambique \\
\hline $\begin{array}{l}\text { Negatu \& Parikh } \\
\text { (1999). }\end{array}$ & $\begin{array}{l}\text { The impact of perception and other factors on the adoption of } \\
\text { agricultural technology in the Moret and Jiru Woreda (district) } \\
\text { of Ethiopia. }\end{array}$ & Ethiopia \\
\hline $\begin{array}{l}\text { Oehmke \& Crawford } \\
\text { (1996). }\end{array}$ & The impact of agricultural technology in Sub-Saharan Africa. & Africa \\
\hline $\begin{array}{l}\text { Adesina \& Baidu- } \\
\text { Forson (1995). }\end{array}$ & $\begin{array}{l}\text { Farmers' perceptions and adoption of new agricultural } \\
\text { technology: evidence from analysis in Burkina Faso and } \\
\text { Guinea, West Africa. }\end{array}$ & $\begin{array}{l}\text { Burkina Faso and } \\
\text { Guinea. }\end{array}$ \\
\hline
\end{tabular}


Table 2. Case Profiles

\begin{tabular}{|l|l|l|l|}
\hline Case ID & Industry details & Sector & Country \\
\hline A1 & Agri-tech software & Agri-tech & Ghana \\
\hline A2 & Market research & Agri-tech & Ghana \\
\hline A3 & Crowdfunding & Agri-tech & Ghana \\
\hline A4 & Engineering & Agri-tech & Nigeria \\
\hline A5 & Rice processing mills & Agri-tech & Nigeria \\
\hline M1 & Advertising & Media-tech & Nigeria \\
\hline M2 & Games & Media-tech & Nigeria \\
\hline M3 & Data analytics & Media-tech & Nigeria \\
\hline M4 & Nonprofit all-inclusive media production & Media-tech & Nigeria \\
\hline M5 & Nollywood & Media-tech & Nigeria \\
\hline M6 & Nollywood & Media-tech & Nigeria \\
\hline M7 & Nollywood & Media-tech & UK/Nigeria \\
\hline M8 & Nollywood & Media-tech & Nigeria \\
\hline
\end{tabular}

